\title{
Impact of Ascorbic and Folic Acids Foliar Application on Yield, Growth and its Attributes of Flax Cultivars
}

\author{
Amina I. El-Shafey ${ }^{1}$ and Sanaa S. Hassan ${ }^{2}$ \\ ${ }^{1}$ Crop Physiology Res. Dept., Field Crops Res. Institute, Agric. Res. Center, Giza, Egypt. \\ ${ }^{2}$ Fiber Crop Res. Dept., Field Crops Res. Institute, Agric. Res. Center, Giza, Egypt.
}

Received on: $28 / 2 / 2016$

Accepted: 28/4/2016

\begin{abstract}
Two field experiments were carried out in 2012/ 2013 and 2013/ 2014 seasons at Etay El-Baroud Agricultural Research Station, to investigate the response of cultivars Sakha 1, Sakha 2, Sakha 3 and Giza 9 to ascorbic and folic acids addition at 50 and $100 \mathrm{ppm}$ on flax growth, fiber and seed yield and yield attributes and quality. Significant differences were detected among the studied cultivars, where; Giza 9 cultivar had significantly shorter plants, technical length, lower plant fresh and dry weights, but it had significantly higher number of fruiting branches, heavier 1000- seed weight, taller fruiting zone and seed yield per plant and Faddan. Ascorbic and folic acids application, generally, increased all the studied traits, especially folic acid at $100 \mathrm{ppm}$ concentration, except for, fiber fineness and seed carbohydrate content. Sakha 2 plants treated with ascorbic acid at $100 \mathrm{ppm}$, had significantly the highest chlorophyll (b) in both seasons, chlorophyll $(\mathrm{a}+\mathrm{b})$ and oil percent in the second season, whereas plants of that variety had the tallest strands when treated with folic acid at $100 \mathrm{ppm}$ in the second season.
\end{abstract}

Key words: Flax, variety, Ascorbic acid, Folic acid, Concentrations, Fiber yield, Quality.

\section{INTRODUCTION}

Flax (Linum usitatissimum, L.) is considered among the important sources of fiber and has been grown as a dual purpose crop (fiber and oil) in many countries as Egypt. EL-Hariri et al. (1998) pointed out the importance of flax as a national economy crop with large possibilities of exportation, fabrication and weaving industry.

Linseed (flax seed) oil quality is usually evaluated depending on the content of essential fatty acids (Johnson et al., 2008). The omega 3, 6 and 9 groups of fatty acids all contains essential fatty acids necessary for good health (Morris, 2004). The main compound responsible for the antioxidant activity is ascorbic acid (Vitamin $\mathrm{C}$ ) which is the most abundant antioxidant in flax seeds (Westscott and Muir, 2003 and Morris, 2005). Also, folic acid (vitamin B) is the most important of B-complex vitamins, because of its essential biochemical function in amino acids metabolism and nucleic acids synthesis (Andrew et al., 2000). Meal remains after oil extraction is fed to animals as a protein supplement (Lay and Dybing, 1989).

Flax plants treated with ascorbic and folic acids significantly had increased growth parameters, as well as photosynthetic pigments. These treatments induced plants flowering and early maturity. Also, improved fiber yield, quality and flax seeds quality (Emam et al., 2011). However, (EL-Bassiouny and Sadak, 2015) reported that ascorbic acid application stimulated the accumulation of total soluble carbohydrates in the flax stem of Sakha 3, Giza 8 and Ariane cultivars.
This investigation aimed to study the effect of two antioxidant vitamins, i.e.; ascorbic acid (ASC or vitamin $\mathrm{C}$ ) and folic acid (FA or vitamin $\mathrm{B}_{9}$ ) on growth, yield and its attributes besides seed protein and oil content of four flax cultivars.

\section{MATERIALS AND METHODS}

The present study was carried out at the Agricultural Research Station, Etay El-Baroud, Agricultural Research Center, in 2012/ 2013 and 2013/ 2014 seasons. Experiments, in both seasons, were carried-out in a split-plot design with five replications. The studied cultivars (Sakha 1, Sakha 2, Sakha 3 and Giza 9) occupied the main plots. Ascorbic and folic acids concentrations (50 and 100 ppm) were allocated to the sub-plots. The sub-plot area was $6 \mathrm{~m}^{2}$. Sowing dates were November $3^{\text {rd }}$ in both seasons at $70 \mathrm{~kg} /$ Faddan. Ascorbic and folic acids with the two concentrations sprayed two times at (50 and 70 days after sowing). Cultural practices were applied as recommended for commercial production of flax. The following characters were recorded, for each sub-plot, in both seasons:

1-Vegetative characters: plant fresh and dry weights at 90 and 120 days after sowing (DAS), plant height at 90,120 DAS and harvest, technical length (average of 10 randomly-chosen and guarded plants).

2-Yield attributes: fruiting zone, number of fruiting branches, number of capsules and seeds/ plant and seed yield/ plant (average of ten randomlychosen and guarded plants).

3 -Seed and fiber yield $(\mathrm{kg} /$ Faddan): conversion of seed and fiber yields obtained from each sub- 
plot $\left(6 \mathrm{~m}^{2}\right)$ to its equivalent seed and fiber yield (kg/ Faddan). After harvest and deseeding plants, retting process was carried out on straw for determination of fiber percentage as follows:

Total Fiber $(\%)=\frac{\text { Fiber yield }(\mathrm{kg} / \mathrm{plot})}{\text { Straw yield }(\mathrm{kg} / \mathrm{plot})} \times 100$

4-Fiber fineness (N.m): fiber fineness in metrical number (N.m) was determined according to Radwan and Momtaz (1966) using the following equation:

$\mathrm{N} . \mathrm{m}=\frac{\mathrm{N} \mathrm{L}}{\mathrm{G}}$

Where, $\mathrm{N}$ : number of fibers (20 fibers each 10 $\mathrm{cm})$, L: fiber length $(\mathrm{mm}), \quad \mathrm{G}$ : weight of fibers (mg).

5- Chlorophyll content (mg/ g. f. wt): was quantitatively determined using the equations reported by Moran and Porath (1980) as following:

Chlorophyll $\mathrm{a}=12.0\left(\mathrm{E}_{663.8}-\mathrm{E}_{750}\right)-3.11$ $\left(\mathrm{E}_{646.8}-\mathrm{E}_{750}\right)$.

Chlorophyll $\mathrm{b}=20.78\left(\mathrm{E}_{646.8}-\mathrm{E}_{750}\right)-4.88$

$\left(\mathrm{E}_{663.8}-\mathrm{E}_{750}\right)$.

Chlorophyll $\mathrm{a}+\mathrm{b}=17.67\left(\mathrm{E}_{646.8}-\mathrm{E}_{750}\right)+7.12$ $\left(\mathrm{E}_{663.8}-\mathrm{E}_{750}\right)$.

6- Oil percentages (\%): was determined by extracting using Soxhlet apparatus according to the method described by A.O.A.C. (1990).

7- Protein percentage (\%): nitrogen content in flax seeds was determined using modified microKjeldahl method. Crude protein content was calculated by multiplying nitrogen content by 6.25 (A.O.A.C., 1988).

8- Carbohydrates content (\%): total carbohydrates in dried flax seeds was determined using phenol sulphuirc method (Dubois et al., 1956).

Data were statistically analyzed according to

Gomez and Gomez (1984).

\section{RESULTS AND DISCUSSION}

\section{Vegetative traits:}

Results presented in Table (1) showed that both, flax cultivars, ascorbic and folic acids concentrations had significant effect on the studied vegetative traits in the two seasons. However, the interaction effects were significant on plant fresh weight at (120 DAS) in the first season, plant height at (90 DAS), harvest and technical length in the second season, besides, plant fresh weight and plant dry weight at (90 DAS) in both seasons.

Concerning flax cultivars plant height, the obtained results revealed that, Giza 9 had the shortest plants at 90, 120 DAS and harvest, respectively, in the first season $(95.32,108.30$ and $112.12 \mathrm{~cm})$ and the respective samples in the second season $(89.04,106.64$ and $115.28 \mathrm{~cm})$. However, Sakha 1 plants were, generally among the tallest at the three plant samples in the two seasons. These results might due to genetic differences among the studied cultivars.

Similar trend observed for technical length, where Giza 9 variety had the shortest technical length $(92.40$ and $93.92 \mathrm{~cm})$ in the first and second seasons, respectively, while Sakha 3 and Sakha 1 had the tallest technical length in the two respective seasons.

Plant fresh and dry weights at 90 and 120 DAS samples, presented results in Table (1), indicated that, there were no obvious trend among the studied cultivars within and between seasons, especially in plant fresh weight. Conversely, Giza 9 plants were approximately of least dry weights.

Regarding ascorbic and folic acids (ASC and FA) concentration effects, on growth traits, results pointed out that, foliar application of both (ASC and FA) at 50 or $100 \mathrm{ppm}$ significantly increased plant height in the three growth samples of both seasons. Foliar application of (FA) at $100 \mathrm{ppm}$ concentration produced the tallest plants $(105.40,117.05$ and $125.0 \mathrm{~cm})$ and $(117.05,122.20$ and $128.50 \mathrm{~cm})$ at 90, 120 DAS and harvest, respectively, in the first and second seasons. Similar results reported by Emam et al. (2011). Folic acid application at 100 ppm gave the tallest technical length $(102.95 \mathrm{~cm})$ in the first season, while foliar application of (ASC or FA) at 50 or $100 \mathrm{ppm}$, significantly increased technical length compared to control in the second season. Also, sprayed flax plants with $100 \mathrm{ppm}$ folic acid produced the heaviest plant fresh and dry weight in both seasons. These results were in agreement with those of Liso et al. (1988) and DeTillio et al. (1999), who reported that, vitamins play an important role in the regulation of cell division and elongation.

With regard to interaction between variety and vitamin concentration effects on flax growth characters, results presented in Table (4) indicated that significantly the tallest plants at (90 DAS) resulted from Sakha 1 treated with 100 ppm (FA), however at harvest Sakha 1 variety treated with 100 ppm (ASC), 50 and 100 ppm (FA) and Sakha 2 treated with $100 \mathrm{ppm}$ (FA) in that season, showed significantly the tallest plants. Sakha 2 variety treated with (100 ppm FA), also gave significantly the tallest technical length $(117.80 \mathrm{~cm})$ in the second season.

Considering plant weight, both Sakha 2 and Sakha 1 treated with $100 \mathrm{ppm}$ (FA) produced significantly the heaviest plant fresh weights at $(90$ DAS) in the first and second seasons, respectively. Sakha 2 treated with $100 \mathrm{ppm}$ (FA) and Giza 9 treated with $100 \mathrm{ppm}$ of (ASC and FA) gave significantly the heaviest plant fresh weight at (120 DAS) in the first season. However Sakha 1 treated with $100 \mathrm{ppm}$ (FA) showed significantly the heaviest plant dry weight $(5.77 \mathrm{~g})$ at (120 DAS) in 2013/ 2014 season. 


\section{Yield and yield components:}

There were significant differences between the studied cultivars in seed and fiber yields and all yield attributes in both seasons, except for, number of seeds/ capsule, biological and straw yields/ Faddan in both seasons and seed yield/ plant in the second season (Table 2). Giza 9 cultivar that had the shortest plants and technical zone, produced the lowest fiber yield $(548.56$ and $596.0 \mathrm{~kg} / \mathrm{fed})$ in the first and second seasons, respectively. On contrast, that variety had the tallest fruiting zone $(21.32 \mathrm{~cm})$ and maximum number of capsules/ plant (20.12) in the first season, 1000-seed weight (11.10 and 11.22 $\mathrm{g}$ ), seed yield (442.39 and $488.56 \mathrm{~kg} / \mathrm{fed}$ ) and seed yield (1.37 and $1.32 \mathrm{~g} /$ plant) in both seasons. However, Sakha 2 significantly followed Giza 9, where it had (5.52) fruiting branches/ plant, 20.12 numbers of capsules/ plant, $1.22 \mathrm{~g}$ seed yield/ plant and $479.03 \mathrm{~kg}$ seeds/ fed in the first season, besides, fruiting zone length $(21.92$ and $23.84 \mathrm{~cm})$ and 1000seed weights (10.85 and $11.08 \mathrm{~g})$ in the two respective seasons.

Obtained results, also revealed that, vitamins foliar application significantly increased flax fiber and seed yields and their attributes compared to control treatment in both seasons, where, treated plant with (ASC or FA) at (50 or 100 ppm) produced higher capsule numbers/ plant, 1000-seed weight, seed yield/ plant and fiber yield/ fed in the second season. On the other hand, $100 \mathrm{ppm}$ FA produced tallest fruiting zone $(22.55 \mathrm{~cm})$, highest number of fruiting branches/ plant $(5.60 \mathrm{~cm})$, biological yield (4.11 ton/ fed) and fiber yield $(654.15 \mathrm{~kg} / \mathrm{fed})$ in 2012/ 2013 season. These findings were in agreement with that obtained by Robinson (1973) Sahu et al. (1993), Andrew et al. (2000), Samirnoff and Wheeler (2000) and ElBassiouny et al. (2005), who improved the performance of (Brassica juncea) and flax cultivars by seed treatment with vitamin $\mathrm{B}_{6}$ (FA) which might be attributed to their effect on regulation of protein and nucleic acid biosynthesis. Barth et al. (2006) reported that, ascorbic acid is very important for the regulation of photosynthesis, flowering and senescence.

Obtained results in Table (4) also, pointed out that, treated Sakha 1, Sakha 2 and Sakha 3 cultivar plants with (100 ppm FA) showed the highest fiber yields $(666.40,679.60$ and $679.80 \mathrm{~kg} /$ Faddan, respectively), in the first season. However, in the second season, untreated Sakha 2 plants with vitamin showed tallest fruiting zone and highest number of capsules/ plant. In the contrary, Sakha 1 and Giza 9 plants treated with 50 ppm of (FA and ASC), respectively, produced the highest number of fruiting branches and seed yield/ plant. Al-Jabir (2010) indicated that ascorbic acid accelerated photothynthesis and carbohydrate production and that led to increased number of flowers and seed production in Jenugreex.

\section{Fiber and Seed quality:}

The studied cultivars were statistically differed in all seed and fiber quality traits, except for, fiber fineness in the two seasons (Table 3). Sakha 1 variety had significantly the lower fiber percentage, stand length, chlorophyll (a) content and protein content in the two seasons and chlorophyll $(\mathrm{a}+\mathrm{b})$ in the first season. Sakha 2 and Sakha 3 seeds had significantly lower carbohydrate and oil percentages, respectively, in both seasons. Differences between the studied cultivars might be due to genetical differences and the interactions with environment.

With regard to vitamin effects, results presented in Table (3) revealed that, vitamin foliar application, significantly increased all the studied traits, except for fiber fineness in the two seasons. Ascorbic acid application at $100 \mathrm{ppm}$ concentration showed significantly higher values of stand length (82.87 and $82.91 \mathrm{~cm})$, chlorophyll a $(1.44$ and $1.55 \mathrm{mg} /$ g.f.wt), chlorophyll b (0.86 and $0.93 \mathrm{mg} /$ g.f.wt) and chlorophyll $\mathrm{a}+\mathrm{b}$ content ( 2.22 and $2.48 \mathrm{mg} /$ g.f.wt), oil (39.87 and $39.04 \%$ ), protein (24.24 and 23.86 $\%$ ) and total carbohydrate (24.11 and $24.46 \%$ ) contents in both seasons, besides, fiber percent $(21.17 \%)$ in the second season. These results, generally, confirmed with those obtained by Robinson (1973), Smirnoff and Weeler (2000) and El-Bassiouny et al. (2005) who reported that, ascorbic acid application had favorable effect on photosynthesis, cell division and differentiation and that led to increased plant and stand height. Beyer (1994) reported that the increase of chlorophyll content due to ascorbic acid application depends on the scavenging of reactive oxygen species by this antioxidant molecule and removing them directly from the cytoplasm. Moreover, it has a supplementary role in protecting or regenerating oxidized carotenoids or tocopherols (Shao et al., 2006).

Considering variety $\times$ vitamin concentration effects on both fiber and seed quality. Results in Table (4) revealed that, Sakha 2 plants treated with (100 ppm ASC) produced significantly the highest chlorophyll (b) content ( 0.92 and $0.96 \mathrm{mg} /$ g.f.wt) in the two successive seasons and chlorophyll $(\mathrm{a}+\mathrm{b})$ content $(2.52 \mathrm{mg} / \mathrm{g}$.f.wt) and oil percent (41.93\%) in the second season. On the other hand, the tallest stand $(85.14 \mathrm{~cm})$ in the second season resulted from (100 ppm FA) application to Sakha 2 variety.

As for, fiber percent, Sakha 1 variety treated with (50 or 100 ppm FA), sakha 2 at (100 ppm FA) and Sakha 3 treated with (50 or 100 ppm ASC and FA) produced significantly the highest values $(21.32,21.66,21.90,21.12,21.60,21.08$ and $21.94 \%$, respectively) in the first season. 



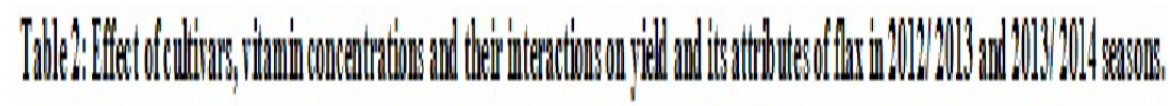

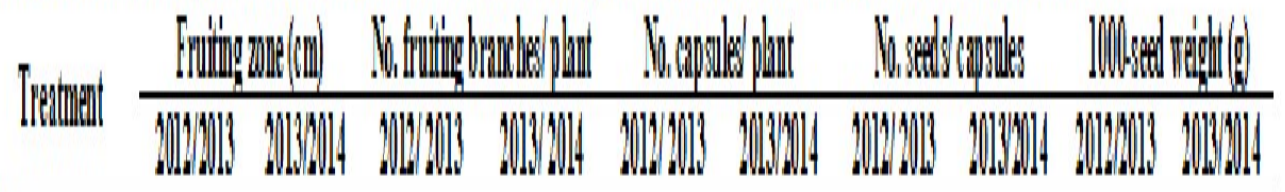

Viats

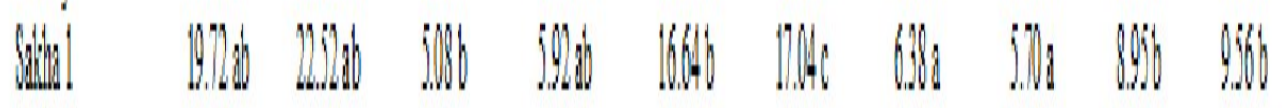

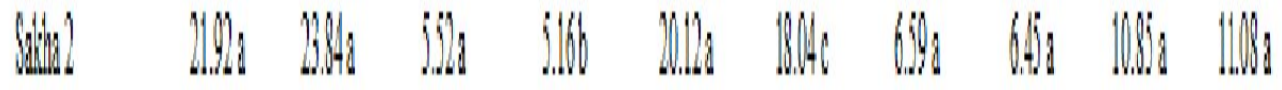

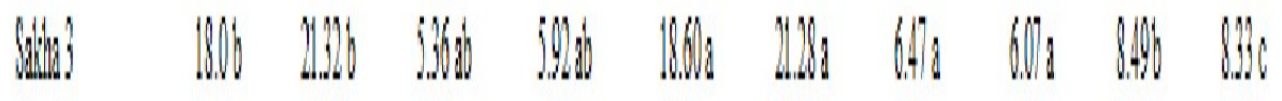

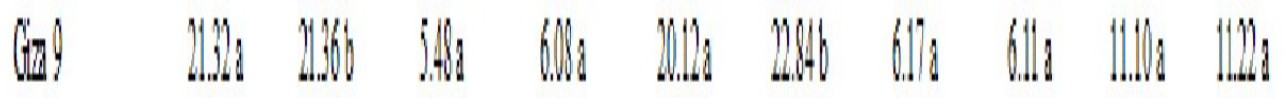

150 III

laming

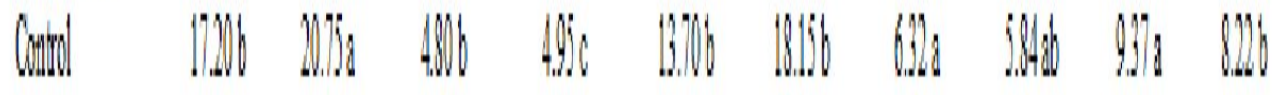

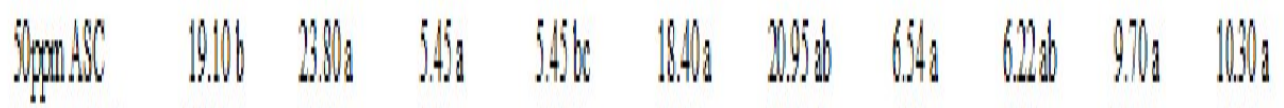

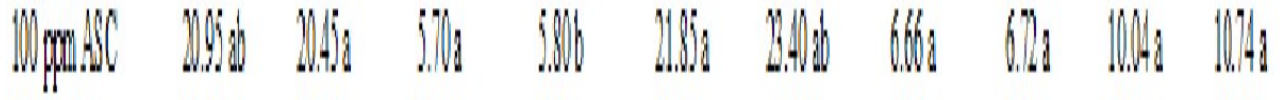

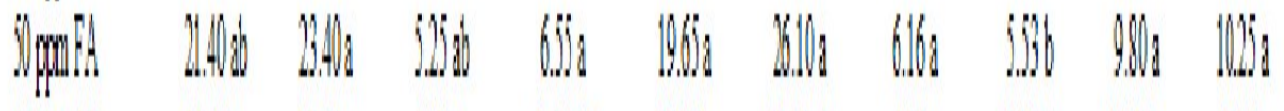

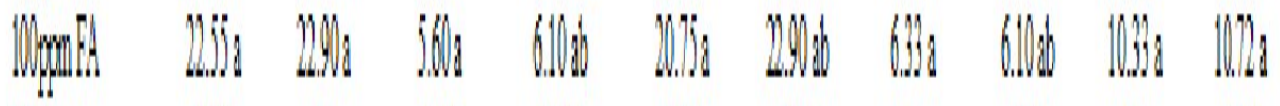
LIV II. ham 11 "

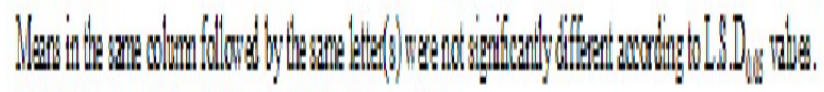

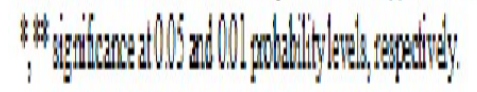




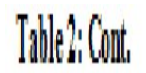

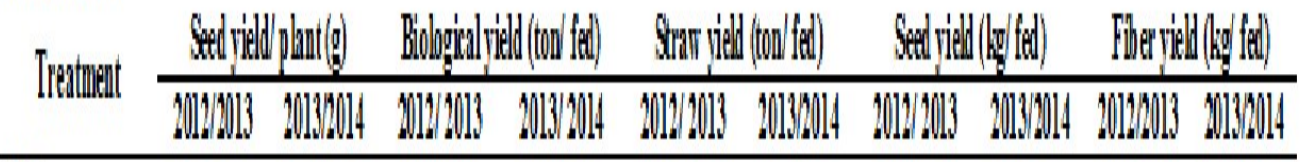

Viaty

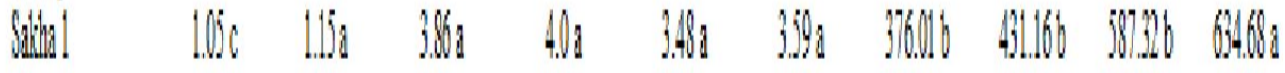

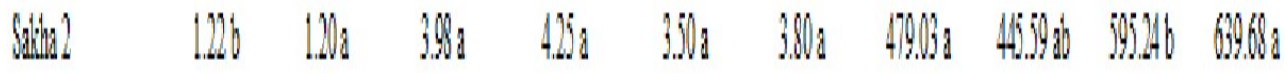

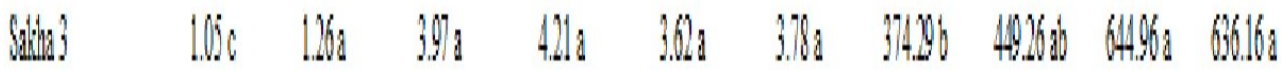

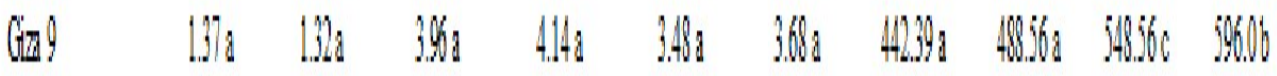

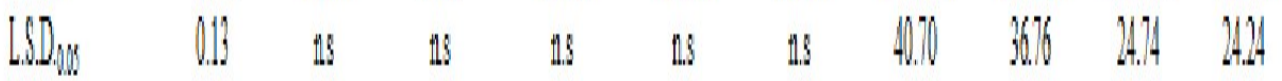

Vianin wome.

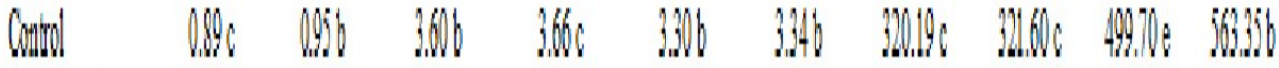

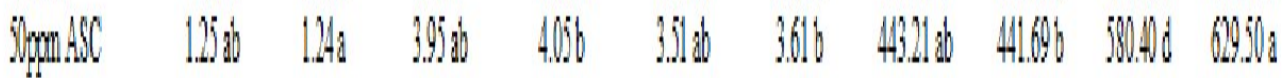

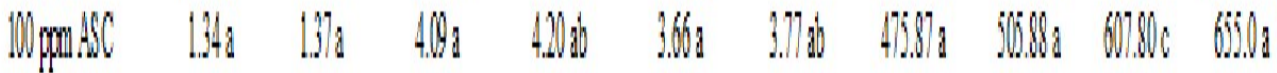

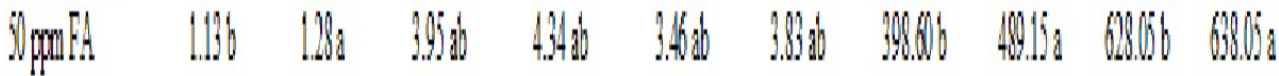

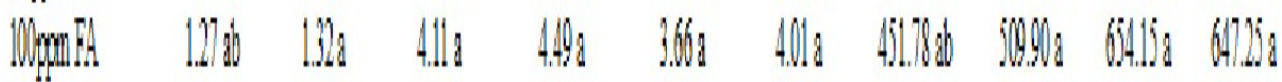

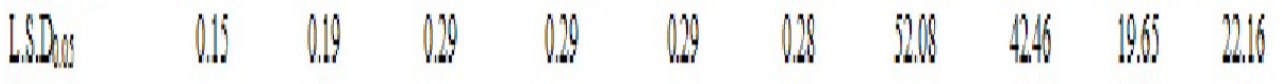

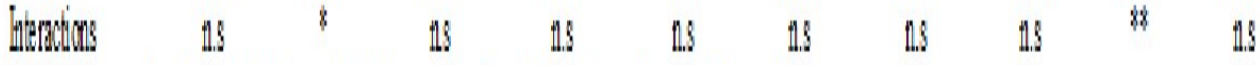

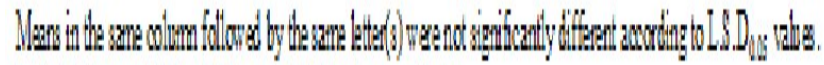

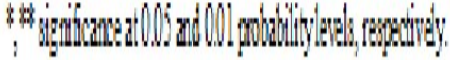




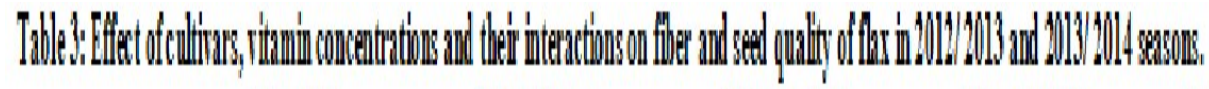

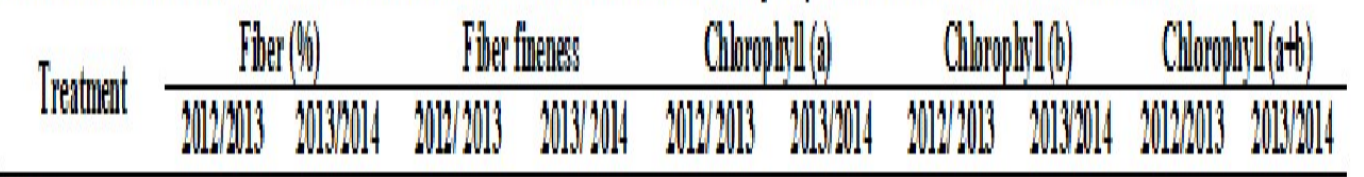

Viave

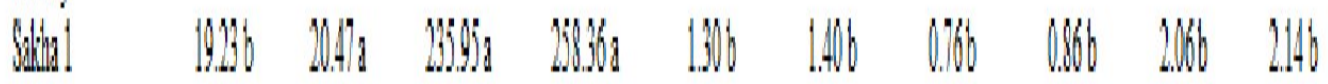

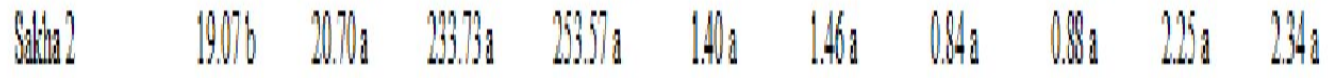

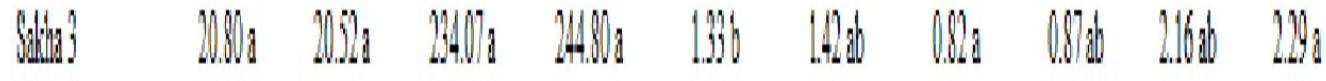

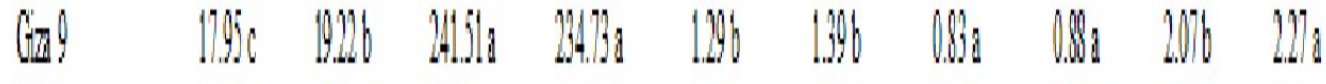

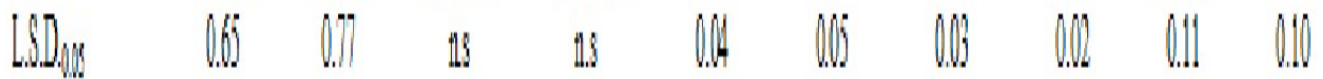

Thromone



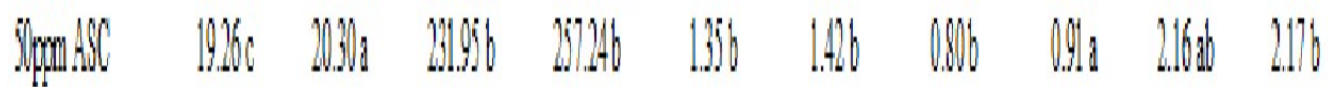

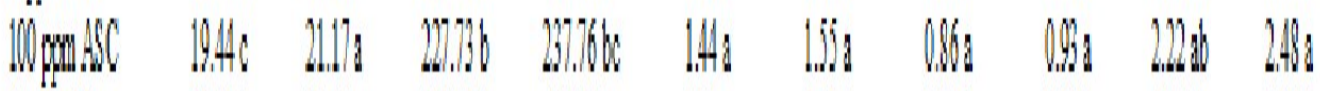

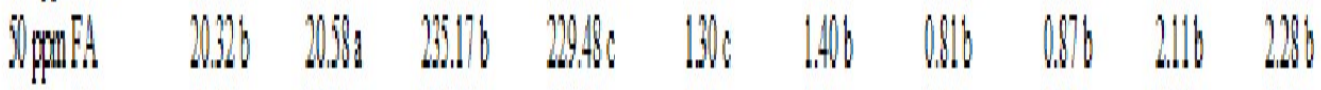

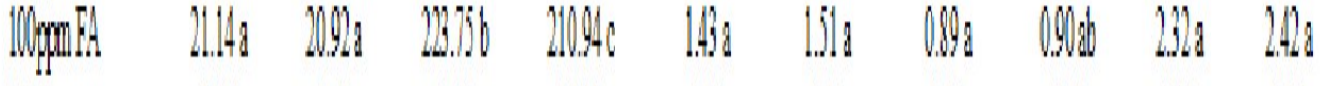

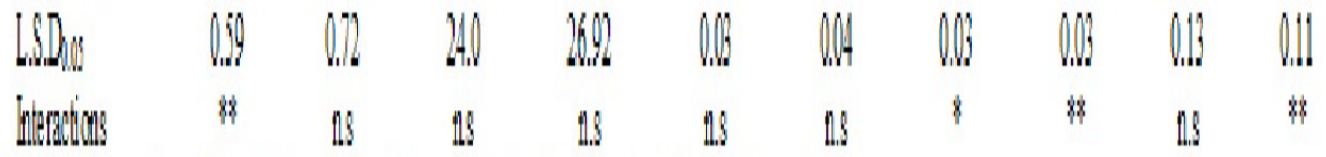

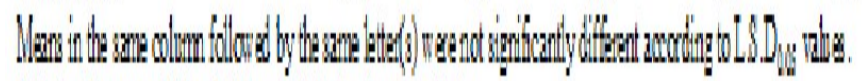

年 


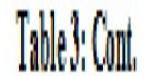

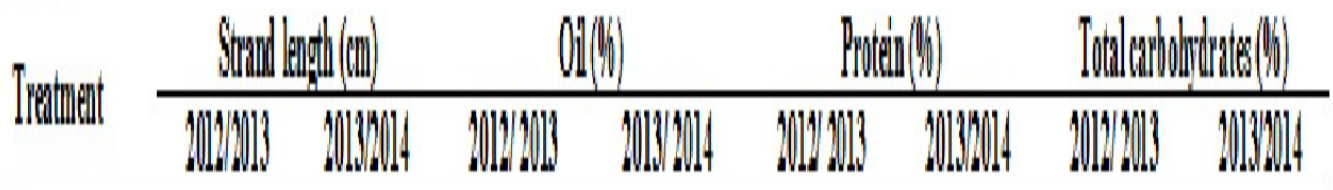

\begin{tabular}{|c|c|c|c|c|c|c|c|c|}
\hline & & & & & & & & \\
\hline Wiili &  & 1948 & Will & $\$ 3$ & 14 & Mhi & 1.460 & 121 \\
\hline Wialial? & a.d & $10 \%$ & Alllla & $y_{1}$ & 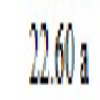 & 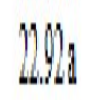 & 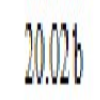 & 10 \\
\hline Wary & 1291 & 1996 & $B H_{C}$ & 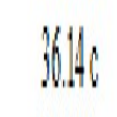 & 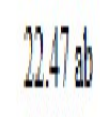 & $\Delta / 6$ & 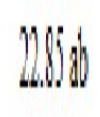 & $8 i$ \\
\hline (ia) & $\operatorname{lng} x$ & 11:16h & $M W^{\prime}$ & 388 & 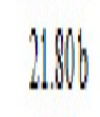 & latib & $B M_{1}$ & De \\
\hline 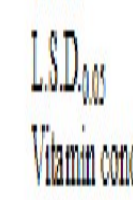 & Q. & 1.1. & (1.) & 0.7 & 0 & & & \\
\hline$(\mathrm{m}$ & 77,66 & 1986 & is & 31660 & WHe & Who & $19 \%$ & 19010 \\
\hline $\mathrm{man}: \mathbb{N}$ & 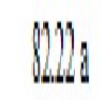 & 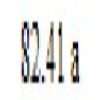 & 34 & 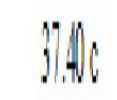 & 12101 & alikh &  & 2336 \\
\hline $11 \mathrm{~mm}$ & 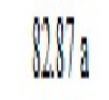 & 891 & 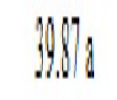 & SWH & $W H_{H}$ & 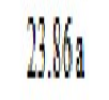 & WHII. & Wh \\
\hline$\| \mathrm{mpl}$ & 81.17 & 0.167 & 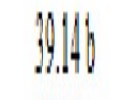 & 1808 & W.4h & 240 & 12120 & 14196 \\
\hline $1 / \mathrm{m} / \mathrm{t}$ & $8 / 12$ & 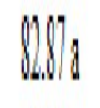 & Ally & $\mathbb{W} \mathbb{W}_{1}$ & $M M_{1}$ & 1860 & $466 \%$ & 1260 \\
\hline 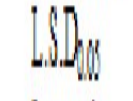 & 18 & 1.10 & (I) & 1.16 & Wal & 0.4 & 161 & |il) \\
\hline thrialaz & If & & $\mathbb{H}$ & & $\mathbb{H}$ & $\mathbb{H}$ & $\mathbb{H}$ & II \\
\hline
\end{tabular}

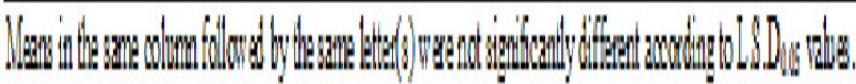

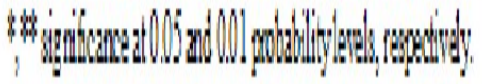




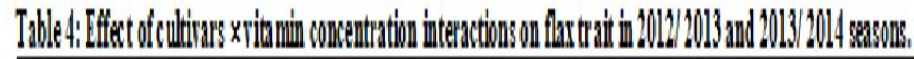

\begin{tabular}{|c|c|c|c|c|c|c|c|c|c|c|c|}
\hline \multirow[t]{2}{*}{ laritity } & Titamin coar, & 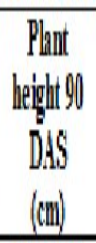 & 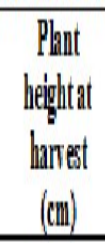 & $\begin{array}{l}\text { Iethinal } \\
\text { length } \\
\text { (min) }\end{array}$ & $\begin{array}{c}\text { Plant } \\
\text { fresh } \\
\text { regighty } \\
\text { D.SS(g) }\end{array}$ & 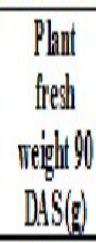 & 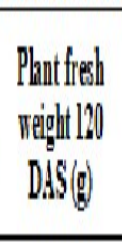 & 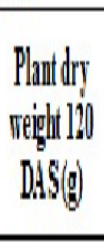 & 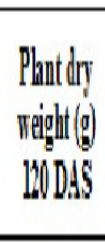 & & 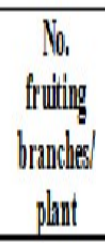 \\
\hline & & $\begin{array}{c}10131911 \\
4\end{array}$ & 20113004 & (1) 131014 & $\begin{array}{c}1011 \% 101 \\
j\end{array}$ & $\begin{array}{c}1013 / 201 \\
4\end{array}$ & 2014013] & [011201] & 101310 & 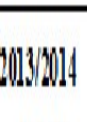 & 1013014.4. \\
\hline \multirow{5}{*}{ Sattal } & Compol. & $900 d$ & 117,660 & 101.860 & 1330 & 1300 & $10.51 \mathrm{~d}$ & 3006 & $301 \mathrm{~W}$ & 1386 & 4.60 \\
\hline & Sbpom $18 C$ & 10280 & 131.1.9b & $106.8 \mathrm{~b}$ & $6.34 d$ & $729 \mathrm{~cd}$ & $11711 \mathrm{be}$ & 3316 & $370 \mathrm{~cd}$ & 24.2. ab & 4.60 \\
\hline & $100 \mathrm{prom} A \mathrm{ACC}$ & $116.68 \mathrm{do}$ & 13429 & 1160.0ab & 8.900 & 13.0726 & 11.01c & 33946 & $4.40 \mathrm{bc}$ & $18.2 b$ & $5.2 c$ \\
\hline & Slopment & $192 \mathrm{do}$ & $1396.6 \mathrm{a}$ & $111.4 d b$ & $9.196 x$ & 13.4986 & $10.7 \%$ & 3.056 & 5.11 b & $27.4 a b$ & 8.28 \\
\hline & $100 \mathrm{pman}$ FA & 10.68 & $135.8 \mathrm{~g}$ & 108.8ab & $1088 \mathrm{ab}$ & $1397 \mathrm{~d}$ & $1355 \mathrm{do}$ & $3778 \mathrm{ab}$ & 5.778 & $27.0 \mathrm{db}$ & $7.0 \mathrm{do}$ \\
\hline \multirow{7}{*}{ Salthe } & Control & $1032 \mathrm{C}$ & $121.146 x$ & 99.16 & $843 c$ & $6360 d$ & $90.0 d$ & 3.176 & $39 \mathrm{jod}$ & 18.28 & $4.4 c$ \\
\hline & Slppon ISC & $108 .+b c$ & 122860 & 97.860 & $733 \mathrm{ded}$ & 8.16ed & $11.5 j b e$ & $38.5 \mathrm{dob}$ & $397 \mathrm{he}$ & $25.0 \mathrm{db}$ & 5.20 \\
\hline & $100 \mathrm{man} A \mathrm{ACC}$ & 111.06 & 124.06 & $102.2 \mathrm{~h}$ & $1171 \mathrm{ab}$ & 11.136 & 1.417\% & 392.60 & 3800 & $21.8 \mathrm{do}$ & $3.60 x$ \\
\hline & $30 \mathrm{pmed}$ & 196660 & 132216 & 1090,06 & 9.066 & $9066 \mathrm{k}$ & 12806 & 41.216 & 4928 & 23210 & 326 \\
\hline & $10 \mathrm{gmanFA}$ & 117.6080 & $198.8 \mathrm{~g}$ & $117.8 \mathrm{~g}$ & {$[231 /$} & 11.076 & $1473 \mathrm{a}$ & A.S3ab & 504020 & 2106 & 5.the \\
\hline & Control. & 8468 & 1.1446 & 9216 & 3990 & $5.70 d$ & $893 d$ & 2896 & 2.48 & $22.2 \mathrm{~b}$ & S. Ato \\
\hline & Slopom $18 \mathrm{C}$ & $1134 \mathrm{~d}$ & 12466 & 1050.0be & 6210 & $10.12 b c$ & $1029 \mathrm{~d}$ & 3.136 & 2.820 & 1966 & 3.660 \\
\hline \multirow[t]{3}{*}{ Sallas? } & $100 \mathrm{pm} A \mathrm{ACC}$ & 110.the & $12212 x$ & $1022 \mathrm{k}$ & $780 \mathrm{CO}$ & $7,4 \mathrm{~N}$ & 12706 & 359.16 & 2798 & 2006 & jobe \\
\hline & SOpm EA & 11286 & 133.the & $99.60 \mathrm{co}$ & $763 \mathrm{~cd}$ & $9.00 \mathrm{bc}$ & 131116 & $4.03 a b$ & $4.660 \mathrm{co}$ & $238 \mathrm{db}$ & 6.2be \\
\hline & $100 \mathrm{gmam}$ FA & $116.68 \mathrm{do}$ & 121.260 & 100.2ho & 8.560 & 10.5360 & $14.61 \mathrm{db}$ & 4939 & 4.846 & 21.06 & 6.60 \\
\hline \multirow{5}{*}{ Ging } & Comed & 7466 & 1098 & 880 & $7.0 \mathrm{~N}$ & 1980 & $10.17 \mathrm{~d}$ & 2876 & 2.43 & 1686 & S. Alue \\
\hline & Slom $\mathrm{BSC}$ & $90.8 \mathrm{de}$ & 121.860 & $95.4 \mathrm{c}$ & B.AlC & $8.60 \mathrm{c}$ & 13006 & $368 \mathrm{ab}$ & $3.12 \mathrm{dd}$ & $26.4 d b$ & $6.9 \mathrm{bc}$ \\
\hline & $100 \mathrm{pm} A \mathrm{ACC}$ & $99.8 \mathrm{de}$ & $117.86 \mathrm{c}$ & $960.0 \mathrm{c}$ & 10.426 & 691 cd & 1.788 & 3.81 .26 & $317 \mathrm{dd}$ & $21.8 \mathrm{ab}$ & 6.60 \\
\hline & SOpm Ex:A & $998 \mathrm{dg}$ & $1119.8 \mathrm{~cd}$ & $94.6 \mathrm{C}$ & 8330 & $8926 \mathrm{cc}$ & 130.06 & 3.1 .420 & $3.43 \mathrm{Cd}$ & $192 b$ & 6.66 \\
\hline & $100 \mathrm{gmanFA}$ & $90.2 \mathrm{de}$ & 118.26 & 99.60 & 8.886 & $\mathrm{BOACd}$ & 14608 & 4.086 & 5.4680 & 22.696 & 5.460 \\
\hline & LS.SDS & 7.4 & 90 & 98 & 161 & 2.45 & 161 & 1.60 & 0.90 & 6.8 & 1.3 \\
\hline
\end{tabular}


Indertic Couth

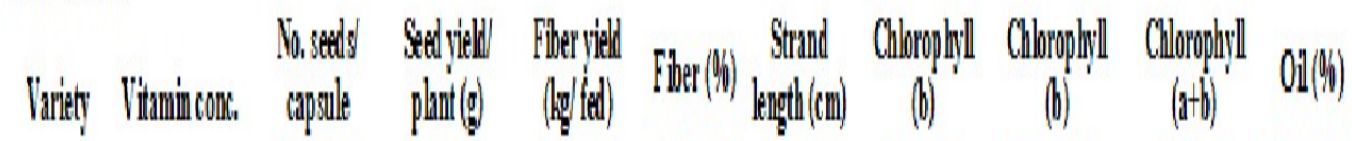

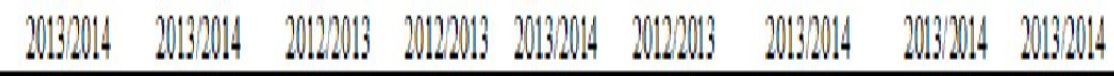

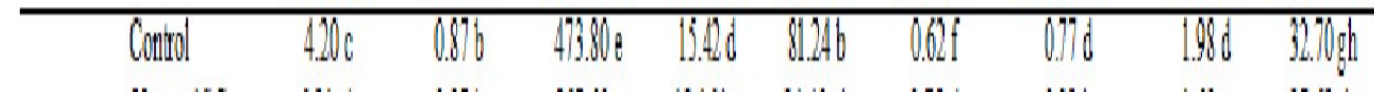



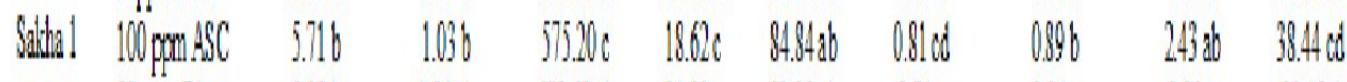



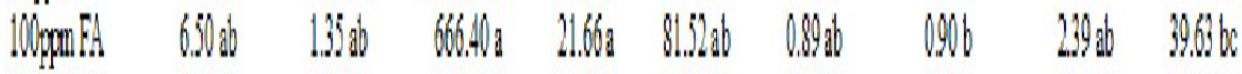

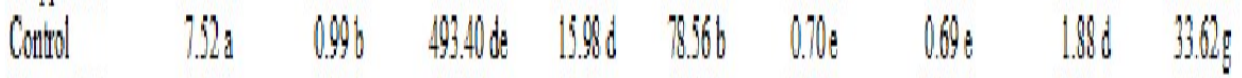

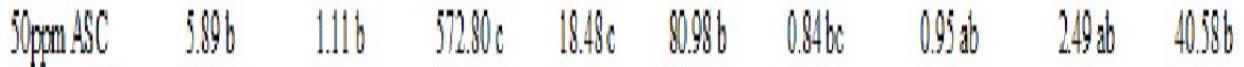

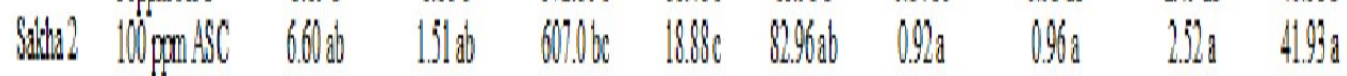

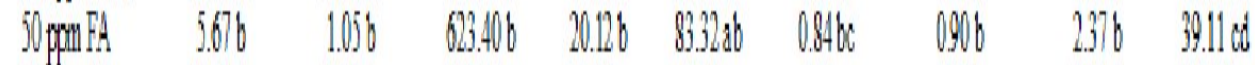

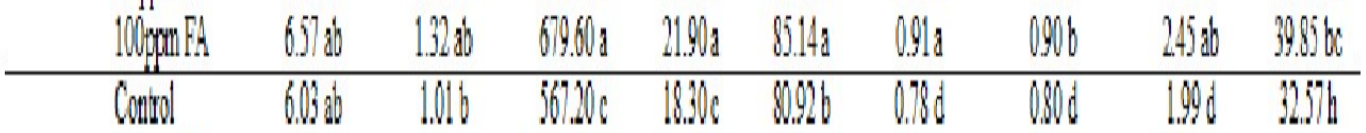

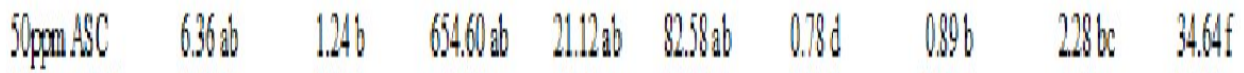

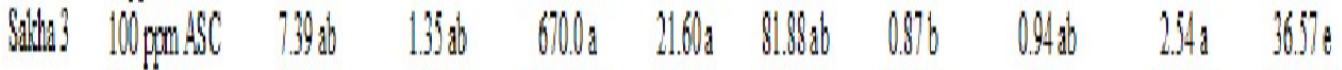

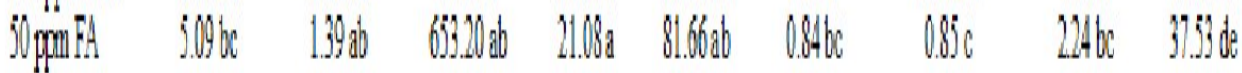



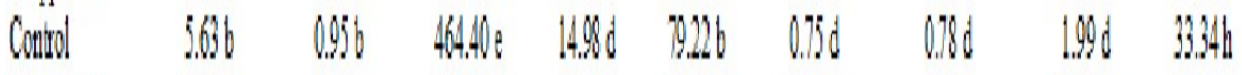

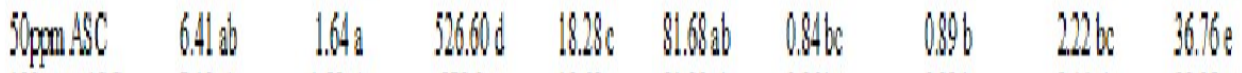

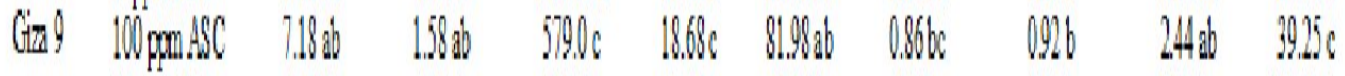

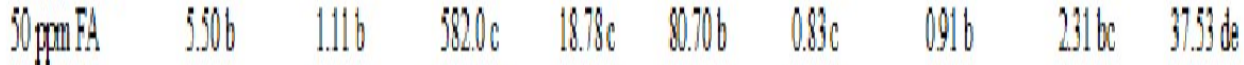

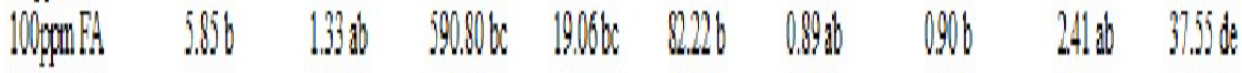

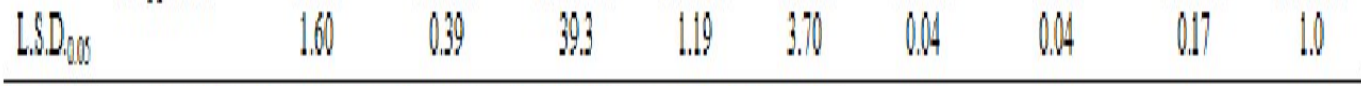

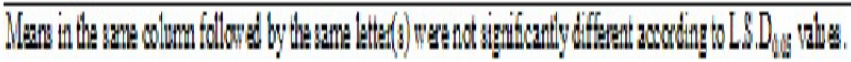


These results clarified that, the studied cultivars were of different response to vitamin concentrations as a results of $\mathrm{G} \times \mathrm{E}$ interaction.

In conclusion, the present study revealed that, there were significant differences among the studied cultivars, in vegetative growth traits and fiber yield. In addition, the present study indicated the beneficial effects of foliar ascorbic and folic acids application on growth, yield and yield components, besides, seed and fiber quality, indicating the possible improvement of fiber and seed yield and quality characters.

\section{REFERENCES}

A.O.A.C., (1988). Official Methods of Analysis $21^{\text {st }}$ Ed., Association of Official Agricultural Chemists, Washington, D.C., USA.

A.O.A.C., (1990). Official Methods of Analysis $15^{\text {th }}$ Ed., Association of Official Agricultural Chemists, Washington, D.C., USA.

Andrew, W.J.; C. Youngkoo; X. Chen and S.G. Pandalai (2000). Vicissitudes of a vitamin. Recent Res. Dev. Phytochem., 4: 89-98.

Barth, C.; M.De-Tullio and P.L. Conklin (2006). The role of ascorbic acid in the control of flowering time and the onset of senescence. J. Exp. Bot., 57: 1657- 1665.

Beyer, R.E. (1994). The role of ascorbate in antioxidant protection of biomembrances interaction with vitamin-E and Coenzyme-Q. J. Bioenerg Biomember., 26: 349- 358.

De-Tillio, M.C.; F.P.D. Vecchia; S. Emerico; L.De Gara; R. Liso and O. Arrigoni (1999). Changes in onion root development induced by the inhibition of peptidyl-prophl hydroxylase and influence of the ascorbate system on cell division and elongation. Planta, 209: 424-434.

Dubois, M.; K.A. Gilles; J.R. Itamilton and F. Smith (1956). Colorimetric method for determination of sugar and related substance. Annal. Chem., 28: $350-356$.

El-Bassiouny, H.M.S. and M.Sh. Sadek (2015). Impact of foliar application of ascorbic acid and $\alpha$-tocopherol on antioxidant activity and some biochemical aspects of flax cultivars under salinity stress. Acta Biol. Colomb., 20(2): 209222.

El-Bassiouny, H.M.S.; M.E. Devarah and A.A. Rarnaden (2005). Effect of antioxidants on growth, yield and favism causative agents in seeds of Vicia faba, L. plants grown under reclaimed sandy soil. J. Agron., 4: 281- 287.

El-Hariri, D.M.; S.H. Mostafa and A.H. El-Sweify (1998). Effect of potassic fertilizer and phytohormone levels on yield attributes, yield and yield quality of flax in sandy soils. $1^{\text {st }}$ Nordic Conf. 10-12 Aug., Tempere, Finland.
Emam, M.M.; A.H. EL-Sweify and N.H. Helal (2011). Efficiencies of some vitamins in improving yield and quality of flax plant. African J. Agric. Res., 6(18): 4362- 4369.

Gomez, K.A. and A.A. Gomez (1984). Statistical Procedures for Agriculture Research. $2^{\text {nd }}$ ed. John Wiley and Sons Inc., New York, USA.

Johnson, M.; S. Ostlund; G. Frausson; B. Kadesjo and C. Gillberg (2008). Omega-3/omeg-6 fatty acids for attention deficit hyperactivity disorder: A randomized placebo-controlled trial in children and adolescents. J. Atten. Disord. PMID, pp. 1844- 1859.

Lay, C.L. and C.D. Dybing (1989). Oil Crop of the World. McGraw-Hill, Inc., New York, USA, P. 427.

Liso, R., A.M.; M.B. Bitonti and O. Arrigoni (1988). Ascorbic acid induced progression of quiescent center cells from G1 to S phase. New Physiologist, 110: 469- 471.

Moran, R. and D. Porath, (1980). Chlorophyll determination in intact tissues using $\mathrm{N}, \mathrm{N}$ dimethyl formamide. Plant Physiol., 65: 478479.

Morris, D.H. (2004). Flax reduces inflammation leading to atherosclerosis. New Flax Facts. Flax Council of Canada, pp. 86-90.

Morris, D.H. (2005). Flax-a smart choice. New Flax Facts. Flax Council of Canada, 465-467 Lombard Ave., Winnipeg, M.B, Canada R3BOT6, Website: www.faxcouncil.ca.

Radwan, S.R.H. and Momtaz, A. (1966). The technological properties of flax fibers and method of their estimation. EL-Falaha J., 46: 466 (In Arabic).

Robinson, F.A. (1973). Vitamins. In Phytochemistry Sol: 195- 220. Lawrence P. Miller (Ed.) VanNostrand Reinhold Co., New York.

Sahu, M.P; N.S. Solanki and L.N. Dashora (1993). Effects of thiourea, thiamine and ascorbic acid on growth and yield of maize (Zea mays, L.). J. Agron. and Crop Sci., 171(1): 65- 69.

Smirnoff, N. and G.L. Wheeler (2000). Ascorbic acid in plant: Biosynthesis and function. Biochem. Mol. Biol., 35 (4): 291- 314.

Shao, H.B.; L.Y. Chu; C.X. Zhao; Q.J. Guo; X.A. Liu and J.M. Ribaut (2006). Plant gene regulatory network system under abiotic stress. Acta Biol. Sezeged, 50: 1-9.

Thompson, L.U.; J.M. Chen, T. Li; K. StrasserWeippl and P.E. Goss (2005). Dietary flaxseed alters tumor biological markers in postmenopausal breast cancer. Clin. Cancer Res., 11 (10): 3828-3835.

Westscott, N.D. and A.D. Muir (2003). Chemical studies on the constituent of Linum spp. Taylor and Francis, London, pp. 55-73. 


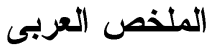

\section{تأثير المعاملة بحامض الإسكوربيك والفوليك على النمو والمحصول ومكوناته لأصناف الكتان}

\section{أمينة إبراهيم الثافعى'، سناء سعبد حسن'}

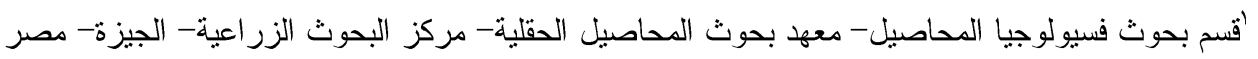

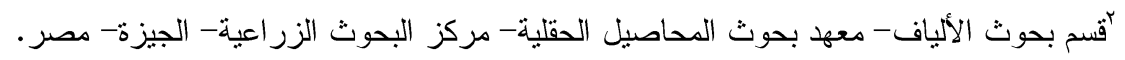

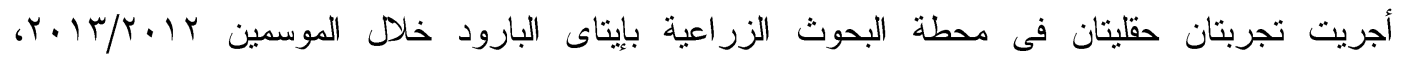

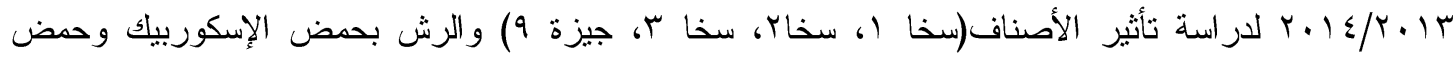

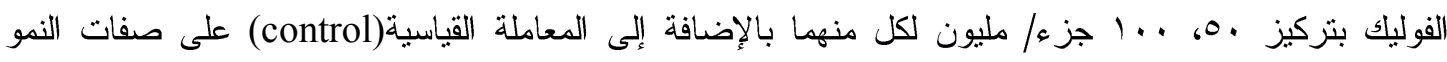

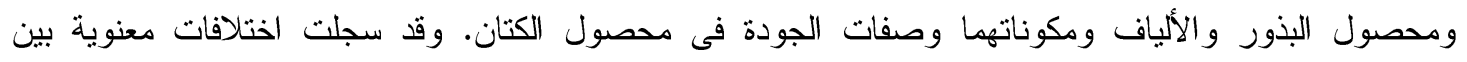

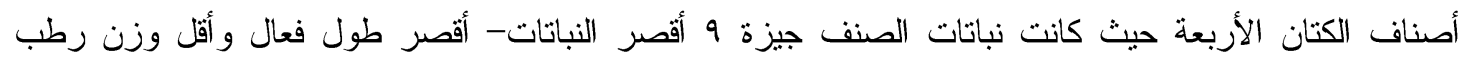

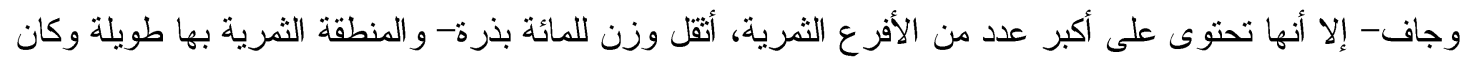

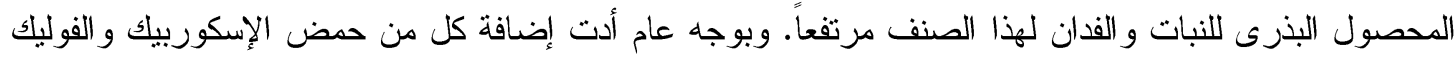

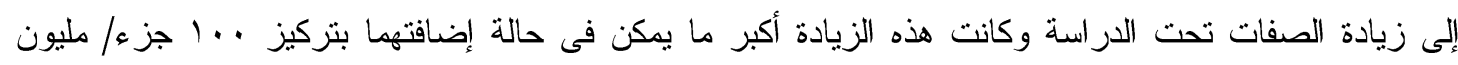

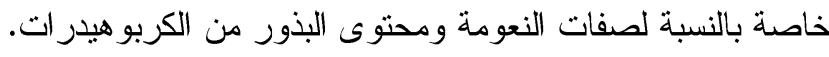

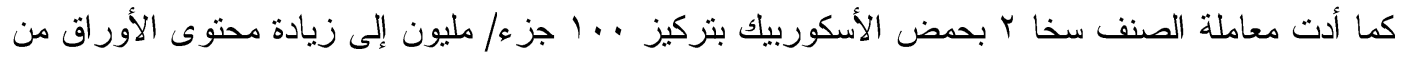

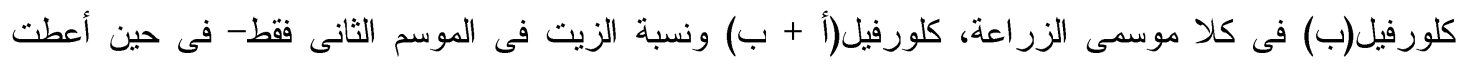

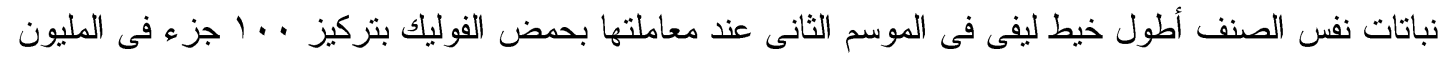

